\title{
Kemampuan Yogurt Sinbiotik Berbasis Probiotik Lokal dalam Mencegah Diare dan Meningkatkan Imunitas Tikus Putih (Rattus norvegicus)
}

\section{The Ability of Local Probiotic Based Synbiotic Yoghurt in Preventing Diarrhea and} Increasing Imunity of Rats (Rattus norvegicus)

\author{
Made Astawan $^{1 *}$, Tutik Wresdiyati ${ }^{2}$, Irma Isnafia Arief ${ }^{3}$, dan Septi Dwi Utami ${ }^{1}$ \\ ${ }^{I}$ Departemen Ilmu dan Teknologi Pangan, Fakultas Teknologi Pertanian, Institut Pertanian Bogor \\ Jln. Raya Dramaga, Bogor 16680 \\ ${ }^{2}$ Departemen Anatomi, Fisiologi, dan Farmakologi, Fakultas Kedokteran Hewan, Institut Pertanian Bogor \\ Jln. Raya Dramaga, Bogor 16680 \\ ${ }^{3}$ Departemen Produksi dan Teknologi Peternakan, Fakultas Peternakan, Institut Pertanian Bogor \\ Jln. Raya Dramaga, Bogor 16680 \\ E-mail:mastawan@yahoo.com *Penulis untuk korespondensi
}

\begin{abstract}
The objective of this study was to observe the ability of synbiotic yoghurt (containing local probiotics Lactobacillus acidophilus 2B4) as an antidiarrhea at rats infected by Enteropathogenic Escherichia coli (EPEC), and also to detect its impact toward immunomodulator characteristics (number of lymphocytes cell, liver malonaldehyde/ MDA level, and liver superoxide dismutase/SOD activity). The orally EPEC infection $\left(10^{7} \mathrm{cfu} / \mathrm{ml} / \mathrm{day}\right)$ into the rats for seven days significantly caused light diarrhea without decreasing of body weight. The oral administration of synbiotic yoghurt containing $10^{9}$ cfu of lactic acid bacteria/ml/day for 21 days significantly increased the imun respons of rats, indicated by increasing of lymphocite cell on the $14^{\text {th }}$ day, decreasing of liver MDA on the $14^{\text {th }}$ and $21^{\text {st }}$ days, and increasing of liver SOD activity on the $14^{\text {th }}$ day.
\end{abstract}

Keywords: Synbiotic yoghurt, MDA, lymphosite, SOD, immunomodulator

\section{Abstrak}

Tujuan penelitian ini adalah mengamati kemampuan yogurt sinbiotik yang mengandung probiotik lokal (Lactobacillus acidophilus 2B4) sebagai antidiare pada tikus yang terinfeksi Enteropathogenic Escherichia coli (EPEC), dan untuk mendeteksi dampak terhadap karakteristik imunomodulator (jumlah sel limfosit, kadar malonaldehid/MDA hati, dan aktivitas antioksidan superoksida dismutase/SOD hati). Infeksi EPEC (10 $\left.{ }^{7} \mathrm{cfu} / \mathrm{ml} / \mathrm{hari}\right)$ yang dilakukan secara oral ke tikus selama tujuh hari berturut-turut secara nyata menyebabkan diare ringan tanpa penurunan berat badan. Pemberian secara oral yogurt sinbiotik yang mengandung $10^{9}$ cfu bakteri asam laktat $/ \mathrm{ml} /$ hari selama 21 hari secara nyata meningkatkan respons imun tikus, yang ditunjukkan dengan meningkatnya sel limfosit di hari ke-14, penurunan MDA hati pada hari ke 14 dan 21, dan meningkatnya aktivitas SOD hati pada hari ke-14.

Kata kunci: Yogurt sinbiotik, MDA, limfosit, SOD, imunomodulator 